Profit: Jurnal Kajian Ekonomi dan Perbankan 2 (1) 2018. P: 1-18

PROFIT : JURNAL KAJIAN EKONOMI DAN PERBANKAN

https://ejournal.unuja.ac.id/index.php/profit

E-ISSN : 2597-9434, ISSN: 26854309

\title{
ETIKA DAN BISNIS PERSPEKTIF EKONOMI ISLAM
}

Antony*

- IAI Nurul Hakim Kediri Lombok Barat

\begin{abstract}
:
Praktek bisnis yang hadir ditengah masyarakat pada umumnya paling tidak dapat digambarkan dengan dua cara pandang, pertama doing business like a business yaitu berbisnis untuk mendapatkan manfaat ekonomi. Kedua doing business not only like a business yaitu berbisnis bukan hanya untuk motif bisnis dengan mengedepankan nilai-nilai yang etis untuk mendapatkan benefit ekonomi. Cara pandang ini melahirkan perilaku yang bersentuhan dengan prinsip keadilan dan nilai kemanusiaan. Antara perilaku bisnis yang bermoral dan a moral.
\end{abstract}

Konsep etika antara pandangan pemikir Barat dan pemikir Islam berjalan beriringan dengan nilai-nilai etisnya. Etika memiliki peranan penting dalam menjaga keseimbangan bisnis, terlepas apakah etika umum atau etika Islam. Menurut Al-Mathuridi (w.333/944) dan Dun Scotus (w.1308) tentang moralitas, bahwa manusia memiliki dua kecenderungan yang berlawanan yaitu kasih sayang untuk keadilan (affection for justice) dan kasih sayang untuk mendapatkan keuntungan (affection for advantages).

Etika Islam merupakan filsafat moral dan ajaran yang syarat dengan nilai-nilai yang sejalan dengan prinsip keadilan dan kemanusiaan. Yang bersumber dari al-Quran, al-Sunnah, Ijtihad. Etika Islam hadir dalam lingkungan bisnis memberikan guidence dan menawarkan pendekatanpendekatan bagaimana menjalankan bisnis yang mendukung tercapainya motif ekonomi para pelaku bisnis tanpa harus mengesampingkan nilai-nilai etik yang dipegang masyarakat

\section{Email :antonysaef@gmail.com Keyword: etika, Etika Islam, prinsip bisnis}




\section{Pendahuluan}

Islam agama universal dan komprehensif. Sebagai agama, Islam memilikiajaranajaran asasiyah dan fundamental, diantara pokok-pokok ajaran Islam tersebut meliputi tiga aspek, akidah, syariah, dan akhlak. Ketiga aspek ajaran Islam tersebut melingkupi holistisitas aktivitas manusia muslim, termasuk di dalamnya aktivitas ekonomi dan bisnis. Etika dalam Islam disebut dengan akhlak..Persamaan makna antara etika dan akhlak dapat ditelusuri pada berbagai kajian.Bedanya etika berasal dari bahasa Yunani dari kata ethos (bentuk tunggal) dan ta etha (bentuk jamak) bermakna adat kebiasaan. ${ }^{1}$ dan akhlak berasal dari bahasa Arab dari kata al-akblakjamaedari al-Khuluqbermakna tabiat, perilaku. ${ }^{2}$ Pemaknaan akar kata secara bahasamengantarkan pada satu pemahamahan awal bahwa etika dan akhlak berbicara tentang sikap dan perilaku manusia.

Untuk memahami etika dengan utuh dan komprehensif, merujuk pada KBBI etika dijelaskan dengan tiga makna, 1) etika adalah ilmu tentang apa yang baik dan apa yang buruk dan tentang hak dan kewajiban moral (akhlak), 2) kumpulan asas atau nilai yang berkenaan dengan akhlak, dan 3) nilai mengenai benar dan salah yang dianut oleh suatu golongan atau masyarakat. ${ }^{3}$ Kajian etika islam dalam tulisan ini meliputi tiga pemahaman etika sebagai ilmu, etika ajaran akhlak dan sebagai nilai yang dianut sekelomkok orang atau masyarakat.

Menghubungkan antara agama dan bisnis seringkali dianggap tabu dalam pandangan sebagian masyarakat, begitu pula dengan pandangan sebagian masyarakat di Indonesia. Dalam praktek bisnis kita dapat menemukan cara pandang (worldview) masyarakat tentang bagaimana mereka mereka melakukan kegiatan atau transaksi bisnis (doing a business) dengan tujuan mendapatkan nilai ekonomi sebagaimana yang diekspektasikan. Pertama, bagi sebagian pelaku bisnis beranggapan bahwa Business is abusiness, urusan bisnis adalah urusan mendapatkan manfaat (benefits) ekonomisebanyak-

\footnotetext{
${ }^{1}$ K Bertens, Etika, 9th ed. (Yogyakarta: Kanisius, 2013).

2Secara etimologi, kata "al Akblak" jama' dari "al Khuluq" memiliki banyak makna, yaitu al-Thabi'ah atau al-Thab'u (tabiat). Secara terminologi, Imam al Ghazali mendefinisikanakhlak dengan, "Ungkapan tentang kondisi yang menetap di dalam jiwa, dimana semua perilaku bersumber darinya dengan penuh kemudahan tanpa memerlukan proses berpikir dan merenung. Lihat, Mohd. Aji Isnaini, “Konsep Akhlak Imam Al Ghazali," Wardah: No.23/ Th. XXII/Desember 2011 (2011): 205-211.
}

${ }^{3}$ Departemen Pendidikan Dan Kebudayaan, Kamus Besar Bahasa Indonesia (Jakarta: Balai Pustaka, 1995). 271. 
banyak sehingga dapat memenuhi kebutuhan dan keinginan seseorang yang tak terbatas, atau tujuan kesejahteraan. Ketika urusan bisnis selesai dan mendatangkan keuntungan, itulah keberhasilan atau kesuksesan bisnis.Cara pandang ini sangat pragmatis dan dapat dikatakan ekonomi bebas nilai.Karena orientasi utamanya adalah tercapainya kebutuhan ekonomis semata.Agama dan bisnis terpisah, masing-masig jalan sendiri-sendiri. Pandangan kedua, menjelaskan bahwa business is not only a business, urusan bisnis itu tujuan utamanya bukan hanya mencarimanfaat ekonomi semata akan tetapi bagaimana bisnis itu bisa mendatangkan manfaat lainnya. Berbisnis harus memperhatikan dan peduli terhadap sikap dan perasaan orang lain.

Dalam perspektif ekonomi Islam, praktek bisnis adalah tidak hanya tentang biaya dan manfaat ekonomi.Faktor penentu keberhasilan bisnis terletak pada hal-hal nonmateri, prinsip-prinsip dan strategi bisnis, manajemen yang baik, SDM yangprofesional, serta sikap dan perilaku etik perusahaan. ${ }^{4}$ Apa yang terjadi pada bisnis modern di Amerika juga menggambarkan problem-problem etik yang memengaruhi kinerja korporasi. ${ }^{5}$ Beberapa riset menunjukkan pentingnya peran etika dalam bisnis.Seperti etika pada tingkat korporasi, riset Victoria menegaskan pentingnya tanggung jawab perusahaan di Australia kepada stakeholder terhadap problem etika bisnis terkait etika promosi. ${ }^{6}$ Atau dalam lingkup non ekonomi, seperti yang disampaikan Rattani tentang pentingya etika pada riset bioetika di negara-negara muslim. Bahkan Houdek mengemukakan Segitiga penipuan diterapkan pada perilaku profesional aktif dalam bidang seperti medis, pendidikan, penelitian dan sain atau kependetaan. ${ }^{8}$ Apa yang diperbincangkan pada beberapa tesis di atas menegaskan pentingnya pendekatan perilaku etis yang disertai dengan perangkat-perangkatnya untuk menjalankan setiap aktivitas yang mengarah kepada perilaku etis.

2 Antoni, "Praktik Bisnis Syariah Usaha Dagang (UD) Toncell Mataram Ntb," el-Hikam IX, no. 2 (2016): 423449.

3 Felix Pomeranz and Felix Pomeranz, "Ethics : Toward Globalization,"Managerial AuditingJournal Vol. 19, no. No. 1 (2004): 8-14.

4 Victoria van Maanen, “Who’s Responsible? The Role Of Stakeholders in Promoting Ethical Business Practices,"Busidate, 2014, www.warringalpublications.com.au.

5 Abbas Rattani and Adnan A Hyder, "Developing an Islamic Research Ethics Framework," Journalof Religion and Health (2017).

6 Petr Houdek, "Professional Identity and Dishonest Behavior," Society 54, no. 3 (2017): 253-260. 
Untuk menjawab tantangan yang dihadapai saat ini, terutama di tengah modernisasi yang terjadi di segala bidang. Dimana secara spesifik dalam tulisan ini akan mempertegas konsep etika Islam dan implikasinya dalam dunia bisnis. Mengingat, hal mendasar yang mencirikan ekonomi Islam sebagai sebuah sistem adalah kesatuan dan keutuhan pengetahuan ekonomi yang etis. Ekonomi Islam bukan semata-mata berbicara tentang ekonomi sebagai sebuah cara berusaha untuk mendapatkan harta atau kesejahteraan, tapi juga kenyataan membuktikan bahwa lingkup kegiatan bisnis tidak hanya menyangkut lingkup ekonomi murni, melainkan menyentuh juga aspek-aspek manusiawi dan etika.

\section{Etika dan Etika Islam; Suatu Kajian Ontologis}

Pembahasan ini mempertegas pentingnya etika dalam kehidupan manusia. Cara pandang manusia akan makna dan tujuan hidup akan mempengaruhi cara pandangnya dalam menjalankan setiap aktivitas kehidupannya. Keluasan kajian dan pengembangan etika ke dalam semua sendi kehidupan menjadikan etika sebagai ilmu pengetahuan yang secara simultan menjadi bahan kajian dan diskusi di kalangan para ilmuwan.Termasuk para ahli filsafat Yunani kuno hingga filsafat modern, maupun filsafat Islam.

Secara teoritis etika merupakan salah satu cabang filsafat, selain Etika Kata moral, moralitas, etika, akhlak, susila, norma merupakan sekumpulan kata dan istilah yang lazim digunakan (contohnya di Indonesia) untuk menjelaskan seperangkat nilai yang dianut dan dipegang oleh sekelompok orang atau masyarakat untuk kemudian memberikan penilaian terhadap suatu perbuatan dan tindakan tertentu apakah diterima atau tidak. Kata etika oleh filsuf Yunani klasik Aristoteles(384-322 SM) dipakai untuk menunjukkan filsafat moral, ${ }^{9}$ yaitu disiplin ilmu yang menjelaskan tentang apa yang secara moral dikatakan baik dan buruk, benar dan salah. Etika juga disebut sebagai sistem atau teori nilai dan prinsip moral. ${ }^{10}$

Dalam memahami konsep etika terdapat dua pengertian, pertama etika yang diterjemahkan sebagaimana asal katanya dari Yunani ethos yang berarti adat istiadat atau kebiasaan. Berupa kebiasaan hidup yang baik seseorang atau kelompok orang

5 Bertens, Etika. 4

6 Peter Singer, "Ethics," Encyclopadia Britannica, Inc., accessed October 31, 2018, https://www.britannica.com/topic/ethics-philosophy. 
(masyarakat) yang diwariskan dari generasi ke generasi melului individu atau sekelompok orang tersebut.Sedangkan etika dalam pengertian yang kedua adalah etika yang dipahami dalam pengertian sekaligus berbeda dengan moralitas, yang jauh lebih luas dari moralitas dan etika dalam pengertian di atas. Etika dalam pengertian kedua ini dapat dipahami sebagai filsafat moral yaitu ilmu yang membahas dan mengkaji nilai dan norma. Sebagaimana dijelaskan oleh Bertens bahwa etika dapat dimaknai sebagai etika dalam pengertian praksis dan etika sebagai refleksi yaitu pemikiran moral apakah seseorang atau kelompok harus berbuat baik atau tidak, atautentang apakah harus melakukan sesuatu atau tidak boleh melakukan. ${ }^{11}$ Di Indonesia juga dikenal istilah susila yang juga dimaknai sama dengan moral.

Moral berkaitan dengan prinsip-prinsip perilaku yang benar dan salah yang bersifat justifikatif.Moral diartikan dengan mengekspresikan atau mengajarkan konsep perilaku yang benar. ${ }^{12}$ Moral berasal dari kata latin Mos yang berarti adat istiadat atau kebiasaan, sedangkan dalam bahasa Indonesia diterjemahkan dengan susila, perikau yang sesuai dengan pandangan umum, yang baik dan wajar yang meliputi kesatuan sosial dan lingkungan tertentu. ${ }^{13}$

Sedangkan norma adalah suatu ukuran, batas, garis pengarah dan kaidah penilaian. Kaidah penilaian ini muncul dari suatu penilaian yang diterima dan didukung oleh masyarakat kemudian dipraktikkan dan berjalan menjadi nilai dalam masyarakat kemudian membentuk norma yaitu suatu standar penilaian yang telah umum dan tetap dalam masyarakat dan telah mengandung sanksi.

Sedangkan akhlak lebih dipahami sebagai pengetahuan tentang perbuatan manusia, yang menggambarkan perilaku, tabiat, tingkah laku antara baik dan buruk, benar dan salah yang menentukan tujuan akhir dari usaha dan perbuatan manusia. ${ }^{14}$ Kata akhlak disinggung dalam al-Quran, seperti di dalam (QS. Al-Qalam: 4) yang menerangkan tentang kemuliaan akhlak Muhammad.

11 Djakfar, Muhammad, Etika ..., 2008. Hal.7

12 "Merriam Webster," https://www.merriam-webster.com/dictionary/moral.

13 Hamzah Ya'kub, Etika Islam (Bandung: cv diponegoro, 1991).

14 John L. Esposito, "Dunia Islam Modern," Ensiklopedi Oxpord (Bandung: Mizan, 2002). 24 
Penjelasan tersebut memberikan pemahaman tentang persamaan dan perbedaan antara moral, etika, norma dan akhlak. konsep akhlak dalam Islam dapat disejajarkan dengan pemahaman tentang etika. Penegasan ini pentik mengingat kata akhlak berasal dari bahasa Arab dan menjadi istilah yang masyhur digunakan dalam Islam. ${ }^{15}$ Persamaan antara akhlak dengan etika adalah keduanya membahas masalah baik dan buruk tingkah laku manusia.Perbedaannya terletak pada dasarnya sebagaicabang filsafat, etika bertitik tolak dari pikiran manusia.Sedangkan akhlak berdasarkan ajaran Allah dan Rasul-Nya. ${ }^{16}$

Filsafat dan agama memiliki hubungan yang erat, keeratan hubungan ini dikarenakan manusia tidak bisa menicptakan pengetahuannya sendiri seperti kertas putih, tanpa peran Tuhan (wahyu).Maka peran wahyu (reveleation) diakui dalam ilmu filsafat.Sehingga agama dikatakan sebagai sumber ilmu.Dalam Islam sumber utama ilmu pengetahuan adalah al-Quran, al-Sunnah dan Ijtihad.Di kalangan pemikir Islam lahir tokoh-tokoh filsafat skolastik Islam (850-1200) pada abad pertengahan, seperti muncul al-Kindi, al-Farabi, Ibnu Sina, al-Ghazali, Ibnu Bajah, Ibnu Tufail, dan Ibnu Rusyd. ${ }^{17}$ Nilai-nilai etis dalam ekonomi menurut Robinson adalah integrity, manners, personality, appearance, consideration, dan tact (taktis) dsingkat dengan IMPACT. ${ }^{18}$

Imam al-Ghazali memiliki empat unsur standarisasi tentang akhlak yang baik apabila keempat unsur ini seimbang maka baik pula akhlaknya yaitu ilmu, emosi, syahwat dan adil. ${ }^{19}$ Ilmu merupakan kebaikan maupun kebagusan dalam melihat mana yang benar dan mana salah, antara yang yang hak dan yang batil dalam, keyakinan yang pada akhirnya akan menimbulkan hikmah sebagai puncak akhlak yang baik. Emosi, keseimbangan emosi serta kebaikannya dapat mencegah dan mengendalikan diri kita sesuai dengan petunjuk hikmah.Sedangkan kekuatan syahwat harus tunduk dibawah kendali akal dan syariat, begitu pula dengan kekuatan adil bisa bagus dan baik dengan menjadikan akal dan syariat sebagai komando untuk urusan syahwat dan emosi.

Al-Mathuridi (w.333/944) dan Dun Scotus (w.1308) memiliki pandangan yang sama tentang etika. Bahwa gabungan sifat manusia tentang moralitas, bahwa manusia

15Mohd. Aji Isnaini, "Konsep Akhlak Imam Al Ghazali."

${ }^{16}$ Syarifah Habibah, “Akhlak Dan Etika Dalam Islam,” Pesona Dasar 1, no. 4 (2015): 73-87

17 Suaedi, Pengantar Filsafat Ilmu, ed. Nia Januarini (Bogor: IPB Press, 2016), https:/ /books.google.co.id. 109-110

${ }^{18}$ Robinson, David, Business Etiquette; Bersikap Benar dalam Berbisnis, Gramedia Pustaka Utama, 1996. Hal.5

${ }^{19}$ Mohd. Aji Isnaini, "Konsep Akhlak Imam Al Ghazali." 
memiliki dua kecenderungan yang berlawanan yaitu kasih sayang untuk keadilan (affection for justice) dan kasih sayang untuk mendapatkan keuntungan (affectionfor advantages). ${ }^{20}$ Pandangan memberikan pemahaman bahwa satu sisi dalam bisnisakan selalu ada godaan untuk maksimalisasi pendapatan dengan meningkatkan keuntungan. Dan pada sisi lain, pelaku bisnis harus menjaga nilai-nilai etika keadilan.

Tujuan dari etika adalah agar manusia mengetahui dan mampu mempertanggungjawabkan apa yang ia lakukan. ${ }^{21}$ Di dalam etika, nilai kebaikan dari tingkah laku manusia menjadi sentral persoalan. Maksudnya adalah tingkah laku yang penuh dengan tanggung jawab, baik tanggung jawab terhadap diri sendiri, masyarakat, alam maupun terhadap Tuhan sebagai sang pencipta. Dalam perkembangan sejarah etika, ada 4 teori etika sebagai sistem filsafat moral yaitu hedonimse, eudonomisme, utiliterisme, dan pragmatisme.Isi dari etika adalah bentuk-bentuk kerendahatian, kedermawanan, dan ketulusan. ${ }^{22}$ Kerendahhatian merupakan kapasitas untuk membuat jarak diri dengan kepentingan pribadinya, menjauhkan ego sehingga ia dapat melihatnya secara objektif dan akurat. Tiga kebaikan utama ini masing-masing berkaitan dengan tatanan manusia.Ketulusan adalah kemampuan untuk mengetahui benda-benda secara aktual dan objektif. Kedermawanan adalah melihat orang lain seperti pada dirinya sendiri, sedangkan kerendahhatian adalah melihat diri sendiri seperti orang lain.

Akhlak dalam al-Quran, dijelaskan sebagai budi pekerti (QS.68;4), adat kebiasaan (QS. As-Syu 'era; 137), perangai,muru'ah dan tabi'at.Al-Gazali menjelaskan akhlak merupakan sifat yang tertanam dalam jiwa yang melahirkan berbagai macam perbuatan dengan mudah dan gampang, tanpa memerlukan pemikiran dan pertimbangan terlebih dahulu.Dalam ajaran Islam dikenal tiga jenis akhlak, akhlak terhadap Allah, akhlak terhadap sesama manusia dan akhlak terhadap lingkungan.

${ }^{20}$ Mustafa Çakmak, “Analogies between Al-Māturīdı̄’s and Duns Scotus’s Ethical Perspectives,”Islam and ChristianMuslim Relations 28, no. 4 (2017): 473-491,https:// www.tandfonline.com/ doi/full/10.1080/09596410.2017.131441.

${ }^{21}$ Suaedi, Pengantar Filsafat Ilmu

${ }^{22}$ Ahmad Tafsir, Filsafat Ilmu; Mengurai Ontologi, Epistemologi Dan Aksiologi Pengetahuan (Bandung: PT Remaja BosdaKarya, 2004). 33. 
Allah Swt telah mengatur hidup manusia dengan adanya hukum perintah dan larangan. Hukum ini, tidak lain adalah untuk menegakkan keteraturan dan kelancaran hidup manusia itu sendiri. Dalam setiap pelaksanaan hukum tersebut terkandungnilainilai akhlak terhadap Allah Swt. Berikut ini beberapa akhlak terhadap Allah Swt yang dapat dimanifestasikan dalam konsep kehidupan uintuk meraih kesuksesan dalam ridha Allah, termasuk dalam rangka menjalankan kegiatan bisnis ${ }^{23}$ :

a. Beriman, yaitu meyakini wujud dan keesaan Allah serta meyakini apa yangdifirmankan-Nya, seperti iman kepada malaikat, kitab-kitab, rasul-rasul, hari kiamat dan qadha dan qadhar. Beriman merupakan fondamen dari seluruh bangunan akhlak islam. Jika iman telah tertanam didada, maka ia akan memancar kepada seluruh perilaku sehingga membentuk kepribadian yang menggambarkan akhlak islam yaitu akhlak yang mulia.

b. Taat, yaitu patuh kepada segala perintah-Nya dan menjauhi segala larangan-Nya. Sikap taat kepada perintah Allah merupakan sikap yang mendasar setelah beriman, ia merupakan gambaran langsung dari adanya iman di dalam hati.

c. Ikblas, yaitu melaksanakan perintah Allah dengan pasrah tanpa mengharapkansesuatu, kecuali keridhaan Allah. Jadi ikhlas itu bukan tanpa pamrih.Tetapi pamrih hanya diharapkan dari Allah berupa keridhaan-Nya. Oleh karena itu, dalam melaksanakannya harus menjaga akhlak sebagai bukti keikhlasan menerima hukum-hukum tersebut.

d. Khusyuk, yaitu bersatunya pikiran dengan perasaan batin dalam perbuatanyang sedang dikerjakannya atau melaksanakan perintah dengan sungguh-sungguh. Khusyuk melahirkan ketenangan batin dan perasaan pada orang yang melakukannya. Karena itu, segala bentuk perintah yang dilakukan dengan khusyuk melahirkan kebahagiaan hidup.

e. Huznudz dzan, yaitu berbaik sangka kepada Allah. Apa saja yang diberikan-Nya merupakan pilihan yang terbaik untuk manusia. Berprasangka baik kepada Allah merupakan gambaran harapan dan kedekatan seseorang kepada-Nya, sehingga

${ }^{23}$ Habibah, "Akhlak Dan Etika Dalam Islam.” 
apa saja yan diterimanya dipandang sebagai suatu yang terbaik bagi dirinya. Oleh karena itu, seorang yang huгnuzan tidak akan mengalami perasaan kecewa atau putus asa yang berlebihan.

6) Tawakal, yaitu mempercayakan diri kepada Allah dalam melaksanakan suaturencana. Sikap tawakal merupakan gambaran dari sabar dan menggambarkan kerja keras dan sungguh-sungguh dalam melaksanakan suatu rencana. Apabila rencana tersebut menghasilkan keinginan yang diharapkan atau gagal dari harapan yang semestinya, ia akan mampu menerimanya tanpa penyesalan.

7) Syukur, yaitu mengungkapkan rasa syukur kepada Allah atas nikmat yang telahdiberikan-Nya.Ungkapan syukur dilakukan dengan kata-kata dan perilaku. Ungkapan dalam bentuk kata-kata adalah mengucapkan hamdalah setiap saat, sedangkan bersyukur dengan perilaku dilakukan dengan cara menggunakan nikmat Allah sesuai dengan semestinya. Misalnya nikmat diberi mata, maka bersyukur terhadap nikmat itu dilakukan dengan menggunakan mata untuk melihat hal-hal yan baik, seperti membaca, mengamati alam dan sebagainya yang mendatangkan manfaat.

8) Sabar, yaitu ketahanan mental dalam menghadapi kenyataan yang menimpadiri kita. Ahli sabar tidak akan mengenal putus asa dalam menjalankan ibadah kepada Allah .Sesungguhnya Allah bersama orang-orang yang sabar. Oleh karena itu, perintah bersabar bukan perintah berdiam diri, tetapi perintah untuk terus berbuat tanpa berputus asa.

9) Bertasbih, yaitu mensucikan Allah dengan ucapan, yaitu denganmemperbanyak mengucapkan subhanallah (maha suci Allah) serta menjauhkan perilaku yang dapat mengotori nama Allah Yang Maha Suci.

10) Istighfar, yaitu meminta ampun kepada Allah atas segala dosa yang pernahdibuat dengan mengucapkan “ astagfirullahal „adzim “ee (aku memohon ampun kepada Allah yang Maha Agung ). Sedangkan istighfar melalui perbuatan dilakukan dengan cara tidak mengulangi dosa atau kesalahan yan telah dilakukan. 
11) Takbir, yaitu mengagungkan Allah dengan membaca Allahu Akbar (AllahMaha Besar). Mengagungkan Allah melalui perilaku adalah mengagungkan nama-Nya dalam segala hal, sehingga tidak menjadikan sesuatu melebihi keagunggan Allah. Tidak mengagungkan yang lain melampaui keagunggan Allah dalam berbagai konsep kehidupan, baik melalui kata-kata maupun dalam tindakan.

12) Do'a, yaitu meminta kepada Allah apa saja yang diinginkan dengan cara yangbaik sebagaimana yang dicontohkan oleh Rasulullah. Do" a adalah caramembuktikan kelemahan manusia dihadapan Allah, karena itu berdoa merupakan inti dari beribadah. Orang yang tidak suka berdo ${ }^{e}$ a adalah orang yang sombong, sebab ia tidak mengakui kelemahan dirinya dihadapan Allah, merasa mampu dengan ushanya sendiri. Ia tidak sadar bahwa semua itu berkat izin dari Allah. Jadi, doa merupakan etika bagi seorang hamba dihadapan Allah swt. Firman Allah sebagai berikut: "Berdoalah kepadaKu, Akuakan kabulkan doa kalian. Sungguh orang-orang yang menyombongkan diri karena enggan beribadah kepada-Ku, akan dimasukkan ke dalam neraka jahannam dalam keadaan bina dina ”. ( Q.S. Ghafur : 60)

Dalam etika Islam nilai-nilai akhlak terangkum dalam bagaimana cara manusia berakhlak kepada Allah, akhlak kepada Rasul dan Akhlak kepada manusia, dan akhlak kepada alam.

\section{Relasi Etika dan Bisnis dan Islam}

Dari beberapa definisi di atas dapat pemahaman dan memberikan batasan bahwa etika atau akhlak adalah ilmu yang menjelaskan arti yang baik dan buruk, menerangkan apa yang seharusnya dilakukan oleh manusia kepada lainnya, menyatakan tujuan yang harus dituju oleh manusia dalam perbuatan mereka dan menunjukkan jalan untuk melakukan apa yang harus diperbuat.

Etika bisnis beranggapan bahwa bisnis, sama seperti ranah kehidupan yang lain, mengandung dimensi moral yang harus dikaji dan dinilai demi kebaikan bersama. Etika bisnis religius meyakini bahwa agama menyediakan sumber-sumber yang berharga untuk kajian dan penilaian moral terhadap bisnis.

Bisnis diartikan sebagai suatu kegiatan yang dilakukan oleh manusia untuk memperoleh pendapatan atau penghasilan atau rizki dalam rangka memenuhi kebutuhan 
dan keinginan hidupnya dengan cara mengelola sumber daya ekonomi secara efektif dan efisien. Skinner mendefinisikan bisnis sebagai pertukaran barang, jasa, atau uang yang saling menguntungkan atau memberi manfaat.Menurut Anoragadan Soegiastuti, bisnis memiliki makna dasar sebagai "the buying and selling of goods andservices". 24

Menjelaskan tentang pengertian tentang bisnis tentu tidak lepas dari pembicaraan tentang ekonomi dan perdagangan.Dengan munculnya beberapa sistem ekonomi dalam teori ekonomi menunjukkan orisinalitas dari sistem ekonomi Islam.Menganut pada teori perdagangan yang berkembang selama ini. Misalnya teori klasik tentang perdagagangan dari kaum merkantilis yang salah satu tkohnya adalah Thomas Munn(1571- 1641). Nilainilai etis dalam ekonomi menurut Robinson adalah integrity,manners, personality, appearance, consideration, dan tact (taktis) dsingkat dengan IMPACT. ${ }^{25}$

Pada masa pra Islam bangsa arab kuno memenuhi kebutuhan hidupnya dengan cara berdagang. Suku quraisy melakukan perjalanan dagang yang dibedakan menjadi dua, yaitu perjalanan musim panas dan perjalanan musim dingin; 1.Perjalanan musim dingin ke wilayah yaman dan etiopia dan perjalanan musim panas ke syam dan irak. Nabi Muhammad memulai karir dagangnya pada usia sekitar 16 atau 17 tahun. Contoh transaksi penjualan yang dipraktekkan Nabi adalah menjual dengan lelang. ${ }^{26}$

Menurut Qardhawi Islam tidak bisa dipisahkan antara ekonomi (bisnis) dan akhlak, sama halnya tidak bisa dipisahkan antara ilmu dan akhlak, politik dan akhlak, perang dan akhlak. Artinya akhlak menjadi nadi dari setiap kegiatan muamalah yang dilakukan oleh umat Islam.

Jika melihat perilaku manusia modern, perilaku mereka sepertinya semakin menjauh dari nilai-nilai moral dan akhlak.Perilaku menjauh ini menegaskan pendapat Bauman tentang sifat manusia yang secara moral bersifat ambivalen, dimana

${ }^{24}$ Hamam Burhanuddin, Etika Bisnis menurut Islam (Suatu Telaah Material-Immaterial Oriented), dalam Yahya Wijaya and Nina Mariani Noor, eds., Etika Ekonomi Dan Bisnis; PerspektifAgama-Agama Di Indonesia (Geneva: Globethics.net, 2014), www.globethics.net.

${ }^{25}$ Robinson, David, Business Etiquette; Bersikap Benar dalam Berbisnis, Gramedia Pustaka Utama, 1996. Hal.5

${ }^{26}$ Afzalur Rahman, Ensiklopedi Muhammad SAW Muhammad Sebagai Pedagang, terj. Dewi Nurjulianti dkk, bandung; mizan, 2009. Hal.11

$11 \quad$ Profit : Jurnal Kajian Ekonomi dan Perbankan 
padahakekatnya manusia itu bukan baik dan bukan pula buruk. ${ }^{27}$ Pada kondisi ini, jika perilaku manusia dihubungkan dengan perilaku bisnis. Maka tidak bisa dipastikan apakah dalam tindakan ekonomi atau bisnis yang dilakukan manusia akan memperhatikan dan mempertimbangkan aspek-aspek moralitas antara baik dan buruk. Ambivalensi inilah yang mengarahkan pada kondisi tertentu untuk sebuah motif manusia akan berusaha memenuhi kebutuhannya itu. Sehingga bisa jadi akan mencapai tujuannya itu dengan cara yang baik atau dengan cara yang buruk.

Bila dikaitkan dengan kegagalan kapitalisme Barat di negara-negara Muslim tersebut, kesadaran bahwa akar kapitalisme bukanlah dari Islam kemudian membangkitkan keinginan untuk merekonstruksi sistem ekonomi yang dianggap "otentik" berasal dari Islam. Apalagi sejarah memperlihatkan bahwa pemikiran ekonomi, telah pula dilakukan oleh para ulama Islam, bahkan jauh sebelum Adam Smith menulis buku monumentalnya The Wealth of Nations. Dengan kerangka berpikir demikian, tulisan ini akan mengkaji permasalahan revitalisasi perdagangan Islam, yang akan dikaitkan dengan pengembangan sektor riil, dimana pelaku bisnis tidak hanya berorientasi pada hal material tetapi juga immaterial.

Dalam sebuah riset terhadap deklarasi PBB dan subsequent Global BusinessCompact.Dengan terus meningkatnya multinasional dan perdebatan tentang apa yangmerupakan nilai-nilai bisnis global didasarkan pada Deklarasi PBB dan Global Compact bisnis. ${ }^{28}$ Delapan faktor moral yang ditemukan untuk menjadi umum dalam semua agama besar, yaitu; jaminan, keadilan/kejujuran, karakter integritas, kasih sayang, lingkungan, toleransi, korban dan keseriusan.Dengan menggunakan metode ilmiah (Aksioma), penulis berpendapat bahwa teisme adalah lebih baik dalam meneliti moral dan dalam nilai bisnis dan pemasaran. ${ }^{29}$ Temuan ini memberikan pemahaman bahwa agama memiliki relasi yang kuat dalam memberikan penjelasan penjelasan tentang bagaimana menjalankan bisnis yang baik.

${ }^{27}$ J Arifin, "Dialektika Etika Islam Dan Etika Barat Dalam Dunia Bisnis,” Millah: Jurnal Studi Agama (2008), accessed November 4, 2018, http://jurnal.uii.ac.id/Millah/article/view/269.

${ }^{28}$ John Fraedrich, Othman Althawadi, and Ramin Bagherzadeh, "A Comparative Analysis of the UN Declaration, Global Business Compact, and Religious Morals in Determining GlobalValues for Business and Their Application to Islamic Marketing," Journal of IslamicMarketing (2018).

${ }^{29}$ Ibid 
Uraian di atas, memposisikan relasi yang kuat dan signifikan bila nilai-nilai etika dan etika Islam dihubungkan dengan konsep bisnis.Terlebih ditengah perkembangan sistem ekonomi yang ditopang oleh tehnologi pada praktek-praktek bisnis modern.

\section{Prinsip Prinsip Etika Islam dalam Bisnis}

Sistem-sistem ekonomi yang telah ada telah mempengaruhi peradaban dunia dalam sistem ekonomi seperti, Kapitalisme, Sosialisme, Marxisme, Negara Sejahtera, dan Neoliberalisme - pada hakikatnya bersandar kepada paham tertentu mengenai keadilan.Perdebatan tentang keadilan itutelah melahirkan sejumlah teori dan prinsipprinsip keadilan.Meskipun para penganjurnya memiliki cita-cita dan pandangan yang samatentang keinginan untuk menegakkan keadilan dalam masyarakat, mereka memiliki perbedaan cukup mendasar dalam menentukan makna dan definisi yang tepat tentang keadilan. Teori-teori keadilan yang menjadi landasan pijak sistem-sistem ekonomi kontemporer itu meliputi Prinsip Egalitarianisme Radikal, Prinsip Perbedaan, Prinsip Berbasis Sumber Daya, Prinsip Berbasis Kesejahteraan, Prinsip Berbasis Balasan, dan Prinsip Libertarian. Memerhatikan prinsip-prinsip dari enam teori keadilan di atas terlihat jelas bahwa teori-teori tersebut mengandung keterbatasan dan kurang memuaskan untuk menjawab persoalan-persoalan ketidakadilan secara komprehensif.

Etika Islam merupakan ajaran yang menjelaskan dan mengatur tentang cara bersikap, berperilaku dalam kehidupan manusia yang dipengaruhi oleh kepercayaan manusia terhadap agama Islam itu sendiri. Etika Islam melingkupi semua aspek dan sendi-sendi kehidupan manusia muslim. Etika dalam Islam melingkupi semua sendi kehidupan individu sebagai hamba dan khalifa, sendi kehidupan dalam keluarga, dalam tatanan hidup bermasyarat, sosial-ekonomi, politik dan bernegara. Pluralitas wacana etika dalam islam merupakan sesuatu yang inheren dalam simbol dan tradiri Islam. ${ }^{30}$

Nilai-nilai yang akhlad dalam Islam yang dapat dijadikan prinsip utama dalam melaksanakan aktivitas bisnis yang syarat dengan etika Islam adalah dengan menjagaAkhlak atau hubungan dengan Allah, manusia dan alam.Hablum minallab (Akhlak kepada Tuhan) dengan tidak berbuat syirik, mengagungkan Allah, bertaqwa, mencintai,

${ }^{30}$ Rattani and Hyder, "Developing an Islamic Research Ethics Framework." 
bertaubat, beribadah, mencari ridho-Nya, berdoa dan meneladani sifat-sifatNya.Implementasi bisnis, bisnis sebagai ibadah kepada Allah, menjadikan Tuhan sebagai pengawas yang utama, menjalankan bisnis sesuai dengan ketentuan-Nya.Hablum minannas (Hubungan dengan manusia), menghormati dan memperlakukan orang dengan baik (manusiawi), memberikan hak dan kepentingan mreka dengan adil, wajar dan transparan).Dan implementasi dalam bisnisnya adalah memperlakukan pesaing dan konsumen secara adil, menjaga kualitas produk demi kepuasan dan keselamatan konsumen, menetapkan harga secara adil dan terbuka, menepati janji dan menjaga objektivitas ukuran (timbangan) dengan konsisten.Sedangkan hablumminal alam dengan memperlakuklan alam sesuai dengan habitatnya dan selalu menjaga keseimbangan ekosistem. Disamping memberi hak dan memelihara kehidupan makhluk lain serta turut memelihara alam lain (yang tidak hidup). Implementasinya dalam bisnis adalah; penggunaan bahan baku dari alam dengan efisien, membuang limbah dengan memperhitungkan lingkungan, konsisten memelihara kebersihan lingkukgan.

Jika kita menelusuri sejarah, dalam agama Islam tampak pandangan positif terhadap perdagangan dan kegiatan ekonomis. Nabi Muhammad SAW adalah seorang pedagang, dan agama Islam disebarluaskan terutama melalui para pedagang muslim. Dalam Al Qurean terdapat peringatan terhadap penyalahgunaan kekayaan,tetapi tidak dilarang mencari kekayaan dengan cara halal (QS: 2;275) "Allah telabmenghalalkan perdagangan dan melarang riba". Islam menempatkan aktivitas perdagangandalam posisi yang amat strategis di tengah kegiatan manusia mencari rezeki dan penghidupan. Hal ini dapat dilihat pada sabda Rasulullah SAW: "Perhatikan olehmusekalian perdagangan, sesunggubnya di dunia perdagangan itu ada sembilan dari sepuluh pintu rezeki”. Dawam Rahardjo justru mencurigai tesis Weber tentang etika Protestantisme,yang menyitir kegiatan bisnis sebagai tanggung jawab manusia terhadap Tuhan mengutipnya dari ajaran Islam.

Dengan munculnya beberapa sistem ekonomi dalam teori ekonomi menunjukkan orisinalitas dari sistem ekonomi Islam.Menganut pada teoriperdagangan yang berkembang selama ini. Misalnya teori klasik tentang perdagagangan dari kaum merkantilis yang salah satu toohnya adalah Thomas Munn(1571- 1641). 
Pada masa pra Islam bangsa arab kuno memenuhi kebutuhan hidupnya dengan cara berdagang. Suku quraisy melakukan perjalanan dagang yang dibedakan menjadi dua, yaitu perjalanan musim panas dan perjalanan musim dingin; 1.Perjalanan musim dingin ke wilayah yaman dan etiopia dan perjalanan musim panas ke syam dan irak. Nabi Muhammad memulai karir dagangnya pada usia sekitar 16 atau 17 tahun. Contoh transaksi penjualan yang dipraktekkan Nabi adalah menjual dengan lelang. ${ }^{31}$

Prinsip-prinsip perdagangan yang dicontohkan Rasulullah saw adalah prinsip keadilan dan kejujujuran. Dalam Islam konsep perdagangan yang jujur adalah QS.2;279 yaitu tidak ada unsur kezaliman, baik menzalimi orang lain atau menjadi korban. Rasulullah pernah melakukan intervensi dalam menentukan harga barang ketika terjadi situasi dimana harga barang melambung naik.Peningkatan harga tersebut disikapi oleh para sahabat dengan mengajukan saran agar Rasulullah mematok harga barang tersebut hingga tidak mengalami peningkatan lagi. Kemudian Rasulullah menolak sambil berkata: Sesunggubnya Allab lah yang menentukan harga, yangmenahan dan melapangkan rezeki. Sangat aku harapkan bahwa kelak aku menemui Allah dalam keadaan tidak seorangpun dari kamu menuntutku tentang kezaliman dalam darah dan harta (HR.Anas)

Pada tingkat korporasi, perusahaan berkembang menjadi agen moral yang bertanggung jawab dan memberikan kerangka kerja yang efektif dapat digunakan untuk praktek-praktek bisnis yang berkelanjutan dalam suasana Islam.Terdapat beberapa prinsip-prinsip etika Islam yang dapat diimplementasikan, seperti ikhlāṣ (ketulusan), ' ilm (pengetahuan), hikmah (kebijaksanaan), hilm (masa kesabarannya) dan rifg (kelemahlembutan), sabar (kesabaran), tawaadu' (kerendahan hati), qudwah (contoh yang baik), busnul-Istimaa' (mendengar), shajaa'ah (keberanian), karam(kemurahan hati) ke dalam praktek-praktek bisnis perusahaan. ${ }^{32}$ Penelitian ini merupakan upaya untuk membawa agama ke dalam kehidupan ekonomi, yang berarti selalu membawa etika agama ke dalam apa yang seharusnya bebas dari nilai-nilai tersebut.

31 Afzalur Rahman, Ensiklopedi Muhammad SAW Muhammad Sebagai Pedagang, terj. Dewi Nurjulianti dkk, bandung; mizan, 2009. Hal.11

32 Abdulgafar Olawale Fahm, "Beyond Good Practices and Standards : An Islamic Framework of Sustainable Business Practices for Corporate Organisation,"Islamic Economic Studies 25, no. 3 (2018): 1-18, http://platform.almanhal.com/CrossRef/Preview/?ID=2-114614. 
Diri sendiri dengan bersikap hati-hati (ikhtiyad) dalam aktivitas, menjagakehormatan diri (murue $a h)$ dan melindungi hak orang lain, bertanggung jawab dalamkewajiban. Implementasi bisnisnya adalah dengan bersikap jujur, adil, hormat, menepati janji, dan transparan dalam melakukan bisnis dengan keyakinan bahwa segala apa yang dilakukan akan kembali pada diri sendiri. ${ }^{33}$

\section{Kesimpulan}

Konsep etika berhubungan erat dengan konsep akhlak dalam islam, sehingga muncul istilah etika Islam. Etika Islam merupakan bagian dari pokok-pokok ajaran Islam yang lebih spesifik menekankan pada ajaran moral, yaitu bagaimana harus bersikap dan berperilaku.Sehingga perilaku moral dapat menjadi justifikasi apakah seseorang berbuat baik atau berbuat buruk.

Manusia dalam berbisnis akan selalu dihadapkan pada dua pilihan yang bertentangan, apakah dia akan berbuat baik dengan mengedepankan etika untuk kepentingan keadilan. Atau melanggar nilai kebaikan dengan berbuat ketidakadlian untuk kepentingan pribadinya.

Etika Islam memberikan jalan tengah dimana aktivitas ekonomi dan bisnis tidak selalu dioerientasikan untuk kepentingan maksimalisasi keuntungan atau benefet ekonomi.Melainkan mengarahkan untuk mengendalikan dua kepentingan yang berlawanan tersebut sebagaimana dijelaskan al-Ghazali tentang standarisasi akhlakyang baik apabila keempat unsur ini seimbang maka baik pula akhlaknya yaitu ilmu, emosi, syahwat dan adil.

Implikasi etika Islam inilah yang diharapkan dapat mengarahkan manusia dalam menjalankan aktivitas bisnis untuk tidak keluar dari ajaran dan tuntunan yang disampaikan melului al-Quran maupun al-Sunnah.

33 Djakfar, Muhammad, Etika.... hal.35-36 


\section{BIBLIOGRAFI}

Antoni. "Praktik Bisnis Syariah Usaha Dagang (UD) Toncell Mataram Ntb." el-Hikam IX, no. 2 (2016): 423-449.

Arifin, J. "Dialektika Etika Islam Dan Etika Barat Dalam Dunia Bisnis.” Millah: Jurnal

Studi Agama (2008). AccessedNovember4, 2018.http://jurnal.uii.ac.id/Millah/article/view/269.

Bertens, K. Etika. 9th ed. Yogyakarta: Kanisius, 2013.

Çakmak, Mustafa. "Analogies between Al-Māturīêie's and Duns Scotusees Ethical Perspectives." Islam and Christian-Muslim Relations28, no. 4 (2017): 473 491.https://www.tandfonline.com/doi/full/10.1080/09596410.2017.1314431.

Departemen Pendidikan Dan Kebudayaan. Kamus Besar Bahasa Indonesia. Jakarta: Balai Pustaka, 1995.

Esposito, John L. “Dunia Islam Modern.” Ensiklopedi Oxpord. Bandung: Mizan, 2002.

Fahm, Abdulgafar Olawale. "Beyond Good Practices and Standards: An Islamic Framework of Sustainable Business Practices for Corporate Organisation."Islamic Economic Studies 25,no. 3(2018):118.http://platform.almanhal.com/CrossRef/Preview/?ID=2-114614.

Fraedrich, John, Othman Althawadi, and Ramin Bagherzadeh. "A ComparativeAnalysis of the UN Declaration, Global Business Compact, and Religious Morals in Determining Global Values for Business and Their Application to Islamic Marketing." Journal of Islamic Marketing(2018).

Habibah, Syarifah. “Akhlak Dan Etika Dalam Islam.”Pesona Dasar1, no. 4 (2015):

73-87.

Houdek, Petr. "Professional Identity and Dishonest Behavior." Society54, no. 3(2017): 253-260.

van Maanen, Victoria. "Who's Responsible? The Role Of Stakeholders in Promoting Ethical Business Practices.” Busidate, 2014. www.warringalpublications.com.au.

Mohd.Aji Isnaini. "Konsep Akhlak Imam Al Ghazali." Wardah: No. 23/ Th. XXII/Desember 2011 (2011): 205-211.

Pomeranz, Felix, and Felix Pomeranz."Ethics : Toward Globalization.”Managerial Auditing Journal Vol. 19, no. No. 1 (2004): 8-14.

Rattani, Abbas, and Adnan A Hyder."Developing an Islamic Research Ethics Framework." Journal of Religion and Health(2017). 
Singer, Peter. “Ethics.”Encyclopadia Britannica, Inc.Accessed October 31, 2018.

https://www.britannica.com/topic/ethics-philosophy.

Suaedi.Pengantar Filsafat Ilmu. Edited by Nia Januarini. Bogor: IPB Press, 2016. https://books.google.co.id.

Tafsir, Ahmad. Filsafat Ilmu; Mengurai Ontologi, Epistemologi Dan Aksiologi Pengetahuan. Bandung: PT Remaja BosdaKarya, 2004.

Wijaya, Yahya, and Nina Mariani Noor, eds. Etika Ekonomi Dan Bisnis; PerspektifAgamaAgama Di Indonesia. Geneva: Globethics.net, 2014. www.globethics.net.

Ya ${ }^{e e}$ kub, Hamzah. Etika Islam. Bandung: cv diponegoro, 1991.

“Merriam Webster.” https://www.merriam-webster.com/dictionary/moral. 
